NBER WORKING PAPER SERIES

\title{
THE AFTERMATH OF HAMILTON'S “REPORT ON MANUFACTURES”
}

\author{
Douglas A. Irwin \\ Working Paper 9943 \\ http://www.nber.org/papers/w9943 \\ NATIONAL BUREAU OF ECONOMIC RESEARCH \\ 1050 Massachusetts Avenue \\ Cambridge, MA 02138 \\ August 2003
}

I wish to thank Richard Sylla for helpful comments. The views expressed herein are those of the authors and not necessarily those of the National Bureau of Economic Research.

(C)2003 by Douglas A. Irwin. All rights reserved. Short sections of text, not to exceed two paragraphs, may be quoted without explicit permission provided that full credit, including $(\mathrm{C}$ notice, is given to the source. 
The Aftermath of Hamilton's "Report on Manufactures"

Douglas A. Irwin

NBER Working Paper No. 9943

August 2003

JEL No. F1, N7

\section{$\underline{\text { ABSTRACT }}$}

Alexander Hamilton's Report on Manufactures (1791) is a classic document in the history of U.S. economic policy, but its fate in Congress is not well known. It is commonly believed that the report was never implemented. Although Hamilton's proposals for bounties (subsidies) failed to receive support, virtually every tariff recommendation put forward in the report was adopted by Congress in early 1792. These tariffs were not highly protectionist duties because Hamilton feared discouraging imports, which were the critical tax base on which he planned to fund the public debt. Indeed, because Hamilton's policy toward manufacturing was one of encouragement and not protection, those interests shifted their political support from the Federalists to the Jeffersonian Republicans during the 1790 s.

Douglas A. Irwin

Department of Economics

Dartmouth College

Hanover, NH 03755

and NBER

douglas.irwin@dartmouth.edu 


\section{The Aftermath of Hamilton's Report on Manufactures}

$\underline{\text { Introduction }}$

Alexander Hamilton's famous Report on the Subject of Manufactures has cast a long shadow over U.S. trade policy toward industry. Issued in December 1791, the report not only provided theoretical justifications for the promotion of domestic manufacturing, but as a policy document made specific proposals for government action. These proposals included higher import duties on certain final goods, lower import duties on certain raw materials, pecuniary bounties (production subsidies) for selected industries, government assistance for the immigration of skilled workers, among other measures. To this day, the report is often heralded as the quintessential American statement against the laissez faire doctrine of free trade and for activist government policies in favor of manufacturing, including protectionist tariffs.

Yet the aftermath of the report - its reception in Congress and the ultimate fate of its proposals - has been largely overlooked. Many believe that Congress simply ignored the report and therefore it failed to have any immediate influence on policy. Taussig (1931, p. 16) maintains "that [the] famous document had little, if any, effect on legislation." Cooke (1975, p. 374) argues that "it was the only one of his major reports that Congress failed to adopt and that its subsequent influence (particularly on a protective tariff) is indeterminable." In their magisterial book on the period, Elkins and McKittrick (1993, p. 271) note that the "Report on Manufactures was not acted upon at all." Ferling (2003, p. 350) writes that Hamilton's plan for manufacturing, "which was at least a quarter century ahead of its time, died quickly in Congress without coming to a vote."

Hamilton is even viewed as being indifferent to the fate of this report, in contrast to his keen interest in the reports on public credit and a national bank. While Hamilton's earlier 
reports were attended to with great urgency, the Report on Manufactures was not delivered until nearly two years after the initial request had been made. "When the House received and tabled Hamilton's report, they provoked no protest from its author," notes Nelson (1987, p. 994). "Hamilton, who spared no effort to enact his other reports, did nothing to promote the Report on Manufactures as a comprehensive program."

These perceptions are misleading on two counts: Hamilton was not indifferent to the fate of the report, and many of the report's proposals were implemented. It is true that Congress never considered the report as a package and Hamilton's proposals for bounties and other subsidies were not seriously debated. But Hamilton worked to ensure that Congress enacted virtually every tariff recommendation in the report within five months of its delivery. After pushing through the report's tariff proposals through Congress, Hamilton yielded to the political opposition to further government support for manufacturing and decided not to spend additional political capital on the matter when his top priorities were the country's finances and public credit.

Although the report is often associated with protectionist trade policies, Hamilton's proposed tariffs were quite modest, particularly in light of later experience. This reflected his emphasis on the importance of fiscal revenue to fund the public debt. Manufacturing interests were disappointed with Hamilton's moderate policies. Jefferson and Madison opposed the federal intervention advocated by Hamilton, but their alternative trade policy - aggressive reciprocity - began to attract support from domestic interests seeking protection from imports. Indeed, secretaries of the Treasury in their presidential administrations issued reports on manufactures which were strikingly similar to Hamilton's earlier report that Jefferson and 
Madison opposed.

Given the report's importance in the history of U.S. economic policy, this paper explores the reception and immediate legislative impact of the report. After briefly reviewing the contents and proposals in the December 1791 report, the paper turns to Madison's and Jefferson's reaction to it in January and February 1792. In February and March 1792, Congress debated bounties for the cod fisheries and additional revenue proposals involving tariffs, both of which related to Hamilton's report. Finally, the paper examines the turn of manufacturing interests away from the Federalists as the Jeffersonian Republican policy of reciprocity offered the hope of greater relief from foreign competition than Hamilton's revenue-based trade policy.

\section{Hamilton's Report on Manufactures}

In his first annual message to Congress on January 8, 1790, President George Washington noted that the safety and interest of a free people "require that they should promote such manufactories as tend to render them independent of others for essential, particularly military, supplies." Seven days later, the House of Representatives requested that the Secretary of the Treasury "prepare and report to the House, a proper plan or plans, conformable to the recommendations of the President ... for the encouragement and promotion of such manufactories as will tend to render the United States independent of other nations for essential, especially military supplies."2 Twenty three months later, in December 1791, Alexander Hamilton delivered his famous Report on the Subject of Manufactures to Congress.

\footnotetext{
${ }^{1}$ Annals of Congress, 1 (January 8, 1790), p. 969.

2 Annals of Congress, 1 (January 15, 1790), p. 1095.
} 
The drafting and content of Hamilton's report has been discussed extensively elsewhere, but a brief synopsis here can set the stage for its specific policy proposals. ${ }^{3}$ Hamilton made a broad ranging and powerful case for the government promotion of manufacturing. The report opened by attacking the then influential French physiocratic doctrine that agriculture is the ultimate source of all wealth. Hamilton argued that manufacturing is no less valuable or productive than agriculture and, indeed, had many specific economic advantages, such as the increased productivity that comes from enhancing the division of labor, the use of machinery and technical skills, and the added diversity of employment opportunities offered workers.

Hamilton then addressed the proposition often associated with Adam Smith, "that Industry if left to itself, will naturally find its way to the most useful and profitable employment: whence it is inferred, that manufactures without the aid of government will grow up as soon and as fast, as the natural state of things and the interest of the community may require." Hamilton argued that "the incitement and patronage of government" was required in order to overcome the inertia against starting manufacturing production, namely, "the strong influence of habit and the spirit of imitation - the fear of want of success in untried enterprises - the intrinsic difficulties incident to first essays toward a competition with those who have previously attained to perfection in the business to be attempted - the bounties premiums and other artificial encouragements, with which foreign nations second the exertions of their own Citizens in the branches, in which they are to be rivalled." ${ }^{4}$ In Hamilton's view, this last factor - the artificial encouragements in other countries - constituted a formidable obstacle. This meant that domestic

${ }^{3}$ See Cole (1938), Cooke (1975), and Nelson (1979).

${ }^{4}$ American State Papers, Finance, Vol. 1, p. 128. 
manufacturers not only had to contend with the "natural disadvantages of a new undertaking," but also "the gratuities and remunerations which other governments bestow" on their own producers.

After discussing the current conditions in the United States in relation to manufacturing, particularly the high price of labor and the scarcity of capital, the report shifted to the means by which manufactures could be promoted by government. Hamilton analyzed various trade measures, including import duties, pecuniary bounties (subsidies), patents, and other government policies. Hamilton rated bounties as "one of the most efficacious means of encouraging manufactures, and it is in some views, the best. . . though it is less favored by public opinion than other modes." ${ }^{\prime 5}$ Bounties had the advantage of being a more direct and positive type of encouragement that, unlike import tariffs, did not create scarcity and raise domestic prices. Hamilton also believed that bounties could conciliate the agricultural and manufacturing interests of the country, which might otherwise conflict over tariff policy. For example, if the revenue from duties on cotton manufactures was used to subsidize the use of cotton by domestic textile producers, then agricultural interests would be served and not offended by the intervention.

Hamilton suggested that surplus customs revenue could be used to finance various bounties on production, possibly through a government established and funded board for promoting Arts, Agriculture, Manufactures, and Commerce. The board would provide defray expenses of emigration of manufactures, provide financial prizes for inventors to promote technological improvements, and the like. Recognizing the public's prejudice against having the

5 Ibid., p. 143, 136. 
federal government give money away to select interests and concerns about the possibility of fraud, Hamilton proposed that the board be fully transparent and only exist for three years, after which it could be reconstituted and renewed.

Finally, Hamilton's report turned to specific proposals for policy with respect to a long list of itemized commodities. Hamilton proposed an increase in tariff rates on just over twenty individual commodities, reductions in tariff rates on five raw materials, and government bounties (subsidies) to five separate industries. These specific recommendations involved rather modest changes in existing tariffs. Most of the tariff increases involved moving the assessed duties from five to ten percent. The tariff reductions on raw materials used in domestic manufacturing - raw wood, raw copper, raw cotton, raw silk, and sulfur (for gunpowder) - entailed the elimination of a five percent duty.

Despite the stress placed on bounties in the report, Hamilton proposed subsidies only for domestic producers of coal, raw wool, sail cloth, cotton manufactures, and glass (window and bottles). Perhaps this list of candidates for bounties was short because Hamilton recognized the political realities of the day, that funds for bounties were not plentiful and Congressional support for bounties was not strong. Alternatively, he may have wanted to limit the use of bounties to just a select number of industries. For the most part the degree of subsidization was left unspecified, although Hamilton did propose that cotton textile producers receive one cent per yard produced and one cent per pound of domestic cotton purchased. In any event, except for these five bounties, most of the specific proposals in the report consisted of slight increases or decreases in existing tariffs. 
Early Reaction to Hamilton's Report

Congress apparently tabled Hamilton's report after receiving it, with no clear indication of when it would be taken up for debate. Whenever that debate was to take place, however, James Madison (in the House) and Thomas Jefferson (in the cabinet) were preparing to fight it. Madison and Jefferson believed that bounties were unconstitutional and, if enacted, would set a dangerous precedent. Hamilton anticipated this objection in the Report, noting that Congress had the express authority under the constitution "To lay and Collect taxes, duties, imposts, and excises, to pay the debts and provide for the Common defence and general welfare." In Hamilton's view, the phrase "general welfare" was "as comprehensive as any that could have been used" and "necessarily embraces a vast variety of particulars." Therefore, it was "of necessity left to the discretion of the National Legislature, to pronounce, upon the objects, which concern the general Welfare, and for which under that description, an appropriation of money is requisite and proper."

Madison contested this interpretation. As he wrote to a colleague in January 1792, less than a month after the report was issued:

"What do you think of the commentary (pages $36 \& 37$ ) on the terms 'general welfare'? The federal Govt. has been hitherto limited to the Specified powers, by the greatest Champions for Latitude in expounding those powers. If not only the means, but the objects are unlimited, the parchment had better be thrown into the fire at once."7

${ }^{6}$ American State Papers, Finance, Vol. 1, p. 136.

7 Papers of James Madison, Vol. 14 (January 1, 1792), p. 180. Later that month he wrote: "You know also how extremely offensive some particular measures have been; \& I will frankly own, (though the remark is for yourself alone at present) that if they should be followed by the usurpation of power recommended in the report on manufactures, I shall consider the fundamental \& characteristic principle of the Govt. as subverted. It will not longer be a Govert. Possessing special powers taken from the General Mass, but one possessing the genl. Mass with 
To another correspondent, Madison complained that, because Hamilton's report

"broaches a new constitutional doctrine of vast consequence and demanding the serious attention of the public, I consider it myself as subverting the fundamental and characteristic principle of the Government, as contrary to the true \& fair, as well as the received construction, and as bidding defiance to the sense in which the Constitution is known to have been proposed, advocated and adopted. If Congress can do whatever in their discretion can be done by money, and will promote the general welfare, the Government is no longer a limited one possessing enumerated powers, but an indefinite one subject to particular exceptions."

Jefferson plotted against the report using a similar line of argument. In a February 1792 memo prepared for himself, "Notes on the Constitutionality of Bounties to Encourage Manufacturing," Jefferson stated that import duties were the principal means of promoting manufactures.

"Bounties have in some instances been a successful instrument for the introdn. of new and useful manufactures. But the use of them has been found almost inseparable from abuse. The power of dispensing them has not been delegated by the Constn. to the Genl. Govmt. It remains with the state govmts. whose local information renders them competent judges of the particular arts and manufactures for which circumstances have matured them."9

These notes may have been in preparation for a meeting that Jefferson had with President Washington later that month. In his account of that meeting, Jefferson attacked "the Report on manufactures which, under colour of giving bounties for the encouragement of particular manufactures, meant to establish the doctrine that the power given by the Constitution to collect taxes to provide for the general welfare of the U.S. permitted Congress to take every thing under their management which they should deem for the public welfare, and which is susceptible of the

special powers reserved out of it.” Papers of James Madison, Vol. 14 (January 21, 1792), p. 193.

8 Papers of James Madison, Vol. 14 (January 21, 1792), p. 195.

9 Papers of Thomas Jefferson, Vol. 23 (February 29, 1792), pp. 172-173. 
application of money." ${ }^{10}$ According to Jefferson's notes on the meeting, the conversation ended there, without any apparent reaction from Washington.

Had the report come to the floor of Congress for debate, Madison and his allies were prepared to attack it as violating the Constitution. Yet the report was never presented as a single legislative package and thus the opportunity for a general debate on its proposals never arose. Two important components, however, were almost immediately subject to debate.

\section{The Fisheries Debate, February 1792}

As the report makes clear, Hamilton was well aware of the public's prejudice against bounties. President Washington also foresaw the political trouble that bounties might encounter. As he wrote to Hamilton in October 1791, "The advantages which would result to this Country from the produce of articles which ought to be manufactured at home is apparent but how far bounties on them come within the powers of the Genl. Government or it might comport with the temper of the times to expend money for such purposes is necessary to be considered and without a bounty is given I know of no means by which the growth of them can be effectually encouraged." 11

The resistance in Congress to the appropriation of public funds to assist a particular industry became evident in a debate in early 1792 over financial compensation to cod fisheries for the duty on imported salt used to cure the fish. The existing export bounty on dried fish was thought to benefit merchant traders without really helping the fishermen who bore the direct

10 Papers of Thomas Jefferson, Vol. 23 (March 1, 1792), p. 187.

11 Papers of Alexander Hamilton, Vol. 9 (October 14, 1791), p. 384. 
burden of the salt tax. On the table was a proposal to replace the export bounty with a tonnage bounty paid directly to owners of fishing ships. The measure was assured of fairly broad support: New England Federalists of course supported their local industry, while Jefferson's Report on Fisheries in 1791 was also sympathetic to assistance for the industry. Jefferson supported efforts to improve the competitive position of American fisheries and welcomed the opportunity to strike back at Britain's commercial regulations. But the measure also had strong sectional overtones (most of the fisheries were in Massachusetts) and the use of bounties could spread with this precedent.

The House debate fully revealed this schism. William Giles of Virginia questioned the constitutionality of the proposal, arguing that "there is a great difference between encouragement, and granting a direct bounty." Indeed, Giles was "averse to bounties in almost every shape." 12 Other skeptical members denounced bounties as sectional measures and special interest transfers that reduced national wealth. Federalists such as Fisher Ames of Massachusetts responded that the bounty was not a subsidy and would not cost the Treasury any money. Rather, the bounty was just returning to the fisheries money they had already paid with respect to the salt tax. Elbridge Gerry of Massachusetts proposed to strike out the phrase "bounty allowed" and substitute "allowance made" because "in reality it is no bounty: a bounty is a grant" whereas this was simply a form of rebate. As he explained, "the word 'bounty' is an unfortunate expression, and I wish it were entirely out of the bill."13

Madison then entered the debate, noting the "conflict" that he felt between "my

\footnotetext{
12 Annals of Congress, Vol. 3 (February 3, 1792), p. 363.

13 Annals of Congress, Vol. 3 (February 3, 1792), pp. 374, 376.
} 
disposition on one hand to afford every constitutional encouragement to the fishers, and my dislike on the other, of the consequences apprehended from some clauses of the bill." Madison made the case that government bounties were unconstitutional and would "subvert the very foundation, and transmute the very nature of the limited Government established by the people of America." But Madison made "a material distinction in the present case between an allowance as a mere continuation and modification of a drawback, and an allowance in the nature of a real and positive bounty." The proposal under consideration was thus an "allowance" and not really a bounty and therefore had Madison's support. ${ }^{14}$

In the end, the fisheries bill passed by the comfortable margin of 38 to 21 , as Table 1 shows. But the debate also suggested that attempts to get Congress to enact a general program of bounties would be met with strong resistence. In this instance, though, Madison's position on the fisheries drove Hamilton crazy: "Mr. Madison resisted [bounties to the fisheries] on the grounds of constitutionality, 'till it was evident, by the intermediate questions taken, that the bill would pass $\&$ he then under the wretched subterfuge of a change of a single word 'bounty' for 'allowance' went over to the Majority \& voted for the bill."15

The Tariff Debate, March 1792

In contrast to bounties, Hamilton succeeded fully in pushing the report's tariff proposals

14 Annals of Congress, Vol. 3 (February 6, 1792), pp. 385-389.

15 Papers of Alexander Hamilton, Vol. 11 (May 26, 1792), pp. 437-438. Elkins and McKitrick (1993, p. 277) write that "This sophistry [of replacing the word 'bounty' with 'allowance'] had the effect of recognizing the fisheries as a special case, and at the same time giving the coup de grâce to that entire aspect of Hamilton's report which envisioned a comprehensive system of bounties on industrial products." 
through Congress. Hamilton was handed this opportunity to shape new tariff legislation shortly after the defeat of American forces by western Indians in November $1791 .^{16}$ On March 7, 1792, Congress asked for the Treasury's advice on how to raise additional revenues in order to finance the increased expenditures for the protection of the western frontier.

This request itself proved controversial. Madison and others were greatly concerned about Hamilton's ability to influence Congressional legislation in 1790 and 1791. They charged that such referrals led to undue and corrupt executive influence over the legislature, violating the principle of the separation of powers. ${ }^{17}$ In a deliberate attempt to limit Hamilton's influence on legislation, Madison and his allies strongly opposed this request for Treasury's advice.

However, as indicated in Table 1, the motion passed narrowly, 31 yeas to 27 nays, in a vote that was divided sharply along regional lines: New England voted 14 to 1 in favor and the South voted 6 to 16 against, with the Mid-Atlantic states divided 10 to 11.

Hamilton wasted no time in taking advantage of the House's request and sent his recommendations to Congress just ten days later, on March 17. Hamilton's brief report presented three methods of raising the $\$ 526,000$ required to finance the additional military expenditures: (i) selling the government's stake in the Bank of the United States, (ii) borrowing the funds, (iii) raising taxes. Hamilton objected to the first, arguing that the government should not liquidate its Bank shares. If the government ever decided to dispose of its shares, it should wait for a more opportune time (when securities prices were higher) and devote the revenue to reducing the public debt rather than financing additional expenditures. Hamilton also objected to

16 See Clarfield (1975).

17 See Freeman (2000). 
additional borrowing when the national debt was already so high; as he put it, "Nothing can more interest the national credit and prosperity, than a constant and systematic attention to husband all the means previously possessed, for extinguishing the present debt, and to avoid, as much as possible, the incurring of any new debt." 18

While recognizing that "taxes are never welcome to a community," Hamilton recommended higher import duties. One advantage of the tariffs was that, because "an increase of duties shall tend to second and aid this spirit [of manufacturing], they will serve to promote essentially the industry, the wealth, the strength, the independence, and the substantial prosperity of the country." With this, Hamilton proposed a temporary increase in the base ad valorem rate on imports from 5 percent to 7.5 percent, in addition to permanent changes in the specific and ad valorem duties on a host of specified goods.

Most of the recommendations for ad valorem changes were taken straight from the Report on Manufactures. As Hamilton noted, "It will not escape the observation of the House that the duties which were suggested in the Secretary's report, on that subject, as encouragements to Manufactures, are, for the most part, included among the objects of this report." In addition, "several of the other specific duties which are proposed, besides the inducements to them as items of revenue, are strongly recommended by considerations which have been stated in the report of the Secretary, on the subject of manufactures." 19

Hamilton did not make specific reference to the other proposals in the report, but left it open for Congress to consider them in the future: "It may tend to avoid future embarrassment, if

\footnotetext{
18 American State Papers, Finance, Vol. 1, pp. 158-161.

19 Ibid., p. 161.
} 
such abolitions and drawbacks as shall be deemed expedient, with a view to promoting manufactures, shall accompany the establishment and appropriation of whatever further duties may be laid, for the object in contemplation. And it may be found convenient to qualify the appropriation of the surplus which is to be applied to that object, so as to let in such other appropriations, during the session, as occurrences may suggest."

In April 1792, Congress began debating Hamilton's recommendations. Unfortunately, much of the debate was conducted in the Committee of the Whole and was not recorded in the Annals of Congress. On the floor of the House, the motion was made to raise the duty on imported hemp and cordage and to strike imported cotton from articles exempted from duty. Both of these measures would assist agricultural interests in the South by increasing the price of raw materials, but also raise the cost of producing manufactures. Representative White from Virginia noted that "when it is considered that many of the duties are designed to encourage the manufactures of the United States, he thought that equal attention should be paid to the agricultural interest, an interest as important as any other." This motion passed in a voice vote.

Then, however, a motion was made to give the higher duties an expiration date, making them temporary. The amendment was on the verge of passing, by a margin of 32 to 31 , when the speaker stepped down from the chair and cast a nay vote. Tied at 32 yeas to 32 nays, the measure was defeated. Table 1 indicates the sectional nature of the votes. That this motion nearly succeeded indicates how precarious support was for Hamilton's plan.

From this point, the debate over the bill was brief. John Mercer of Maryland asked whether "the submission of a provision to defend the frontier authorize a system for the encouragement of manufactures? . . . Independent of the constitutional question of the right of 
Congress, why should we be compelled to consider the extensive range and delicate refinement of encouraging manufactures by extensive duties operating as indirect bounties, under the pressure of providing for an Indian war?"20 John Page of Virginia announced his intention of voting against the tariffs, arguing that "it is not a bill for the protection of the frontiers, but for the encouragement of certain manufactures .... It is a bill very different from what it ought to be."21 In contrast, William Murray of Maryland argued that all sectional interests were accommodated in the bill, "particularly the protecting duties by which the hemp and cotton of the Southern states, and the iron of the Middle States, are encouraged and established," as well as the manufactures of the north.

When the votes were cast, the tariff passed comfortably by a vote of 37 in favor and 20 opposed. Once again, Table 1 reveals the North-South divide: members from New England and the Mid-Atlantic states voted 20 to 7 in favor of the bill, while those from the South voted only 7 to 13 in favor. According to Clarfield (1975, p. 459), the tariff increase did not have much political support and passed only by having been tied to increased military expenditures to protect the frontier: "Had circumstances been different, it is extremely doubtful that this tariff proposal would have stood much chance in Congress. By linking military appropriations to the impost, however, Hamilton managed to neutralize a good deal of the opposition."

Thus, Hamilton's tariff proposals in the Report on Manufactures in December 1791 formed the basis for his recommendations to the House in March 1792 and were largely

20 Annals of Congress, Vol. 3 (January 1792), p. 349. This portion of the debate is clearly misplaced as it refers to events that occurred after January; it almost surely took place in late April.

21 Annals of Congress, Vol. 3 (April 21, 1792), p. 569. 
implemented by the Congress in May 1792. Table 2 summarizes Hamilton's proposals in the Report on Manufactures and in March 1792 and how these recommendations compared with the original tariff and the tariff actually enacted in May 1792. As the table makes clear, many of the March 1792 revenue proposals were taken right from the Report on Manufactures. Almost all of Hamilton's proposals for higher tariffs on manufactured goods were adopted. (Notably, he offered no extra assistance to the nascent cotton textile industry.) Where Hamilton did not suggest any change, such as duties on gunpowder and lead, Congress took no action. Hamilton proposed eliminating the import duty on raw cotton (which taxed domestic clothing producers) in 1791, but he made no mention of this in the 1792 report.

In the Report on Manufactures, Hamilton put forward his preference for bounties over tariffs as a means of promoting manufacturers. Although only five specific bounties were mentioned in the report, he did not propose any in his 1792 recommendations, the purpose of which was to suggest ways of raising revenue, not spending it. And although the military debacle on the western frontier paved the way for Hamilton's tariff proposals, it significantly reduced the chance that bounties would be enacted, primarily because of the additional expenditures contributed to a deterioration in the government's fiscal position. (The budget surplus of $\$ 171,000$ in fiscal year 1793 shifted to a $\$ 1,559,000$ deficit in fiscal year 1794.) Even if Congress had viewed bounties in a favorable light, budgetary considerations would have likely prevented any expenditures on them. ${ }^{22}$

${ }^{22}$ However, even if the February debate on a bounty for the fisheries had revealed greater support for bounties, the scandalous collapse of the Society for the Encouragement of Useful Manufactures in March 1792 would have convinced many members of Congress that providing private business ventures with public money would simply result in corruption and waste. 
Because a systematic program of government support for manufacturing was never adopted, the perception remains that the Report on Manufactures was never implemented. Jefferson suggested as much in a letter to President Washington in September 1792, in which he wrote that Hamilton's system “flowed from principles adverse to liberty, and was calculated to undermine and demolish the republic." The system was a threat to the constitution because "in a Report on the subject of manufactures, (still to be acted upon) it was expressly assumed that the general government has a right to exercise all powers which may be for the general welfare." 23 Thus, nine months after Report on Manufactures had been issued, Jefferson believed it was "still to be acted upon." And yet Congress had done all it was going to do with the report, namely, implement its tariff proposals without touching the bounty recommendations or setting up a government board to assist manufacturers.

\section{$\underline{\text { Did Hamilton Favor Protectionism? }}$}

Despite the Report on Manufactures and his support of the Society for the Establishment of Useful Manufactures, Hamilton was not considered a staunch friend by manufacturing interests. The import duties that he proposed were quite modest in comparison to what domestic manufacturers would have liked (and in comparison to those imposed later in the nineteenth century). ${ }^{24}$ In the report, Hamilton was skeptical of high protective tariffs because they sheltered

${ }^{23}$ Papers of Thomas Jefferson, Vol. 24 (September 9, 1792), p. 353. In July 1792 Jefferson wrote a note reminding himself to "condemn report on MANUFACTURES." Ibid., p. 214.

${ }^{24}$ Although 7.5 percent tariffs may not have constitute high protectionist duties, Hamilton stated in the report that the insurance and freight costs of importing gave domestic manufacturers of clothing another 15 to 30 percentage points worth of protection above the 
inefficient and efficient producers alike, led to higher prices for consumers, and gave rise to smuggling which cut into government revenue. This skepticism was evident much earlier in Hamilton's career. For example, in Federalist 35, Hamilton opposed “exorbitant duties on imported articles" as "they tend to render other classes of the community tributary in an improper degree to the manufacturing classes to whom they give a premature monopoly of the market." 25

Hamilton preferred modest duties because, at this stage, he considered import duties as a more important tool of fiscal policy than an instrument for promoting manufactures. Moderate duties would keep imports flowing into the country and provide the revenue that would finance government expenditures and help establish the public credit. "Experience has shown that moderate duties are more productive [of revenue] than high ones," Hamilton wrote in $1782 .{ }^{26}$ Moderate duties gave domestic producers some advantage over foreign producers without compromising revenue and efficiency goal. Indeed, Clarfield (1975, p. 459) has stressed that "the key word in Hamilton's conception was encouragement, not protection" for

foreign price.

25 "There are persons who imagine that [import duties] can never be carried to too great a length; since the higher they are, the more it is alleged they will tend to discourage an extravagant consumption, to produce a favorable balance of trade, and to promote domestic manufactures. But all extremes are pernicious in various ways. Exorbitant duties on imported articles would beget a general spirit of smuggling; which is always prejudicial to the fair trader, and eventually to the revenue itself." Papers of Alexander Hamilton, Vol. 4 (January 5, 1788), p. 477.

26 "When they [duties] are low, a nation can trade abroad on better terms - its imports and exports will be larger - the duties will be regularly paid, and arising on a greater quantity of commodities, will yield more in the aggregate, than when they are so high as to operate either as a prohibition, or as an inducement to evade them by illicit practices." Papers of Alexander Hamilton, Vol. 3 (April 18, 1782), pp. 78-79. 
manufacturers. $^{27}$

The emphasis on moderate duties served the interests of merchants engaged in commerce, such as those in New York, but fell short of meeting the demands of manufacturers who wanted to close the door on imports of foreign (mainly British) goods. Hamilton's reluctance to endorse protectionist duties even began to cost him the political support of domestic manufacturers as petitions for higher tariffs went unanswered. As a result, "By the end of 1793, Hamilton's pro-importer political economy was driving manufacturers from Boston to Charleston into opposition to the Federalists." 28

At first blush, it seems odd that import-competing manufacturers would seek political refuge with the Jeffersonian Republicans. Jefferson and Madison had long been on record as praising the virtues of an agrarian-based economy, fearing the adverse effects of large-scale manufacturing, and resisting federal intervention in the economy. ${ }^{29}$ But even as they opposed the federal government activism that Hamilton desired, Jefferson and Madison were willing to consider much more draconian restrictions on trade than Hamilton's revenue-based fiscal policy

${ }^{27}$ Elkins and McKittrick (1993, p. 261) write that "It would be misleading . . . to picture Hamilton as conjuring up a kind of 'neo-mercantilism'. ... It would be equally misleading to connect Hamilton too closely with the protective-tariff theorists of the nineteenth century, much as they may have looked to him for inspiration. His ends were more complex than theirs, and went well beyond simple protection. (Indeed, a nineteenth century Hamilton would in all likelihood have been a free trader: he did not think it well that any interest should become too settled and comfortable.)"

28 “In 1794 New York's General Society of Mechanics and Tradesmen shifted their support from the Federalists to nascent Republican organizations. It was becoming apparent to many American manufacturers that Hamilton's policies contravened their interests." Nelson (1979), p. 977.

29 On the economic views of the Jeffersonian Republicans, see McCoy (1980). 
would ever allow. They strongly believed that political independence from Britain was incomplete unless accompanied by economic independence from it as well. They called for a policy of aggressive reciprocity and trade sanctions to punish Britain for its restrictive trade policies. They expected (or hoped) that this economic pressure would induce Britain to change its policies, open its markets, and treat neutral shipping with respect. Hamilton vigorously opposed these efforts for fear that they would start a trade war which would reduce U.S. imports from Britain, thereby ruining America's standing on credit markets by shrinking the tax base on which his plans to fund the public debt hinged.

Jefferson and Madison aimed to implement such policies right from the start. In 1789, along with the tariff on imported merchandise, Congress imposed differential duties on the tonnage of American and foreign ships entering U.S. ports. But Madison wanted further discrimination between ships from countries with which the United States had a commercial agreement (such as France) and those with which it had none (such as Britain). Although the measure easily passed the House, it failed in the Senate, where Hamilton apparently worked hard to ensure its demise.

In December 1793, as Secretary of State, Jefferson issued a report to Congress on commercial discrimination, documenting the manifold foreign barriers placed on U.S. goods and shipping in foreign markets. He then outlined a policy of strict reciprocity, in which high duties would be met with high duties and prohibitions with prohibitions, all in an effort to free trade from such impediments. ${ }^{30}$ Such a policy would have meant much higher barriers on import from Britain, but Hamilton and his congressional allies fought strenuously against Madison's

30 See Peterson (1965). 
resolutions in favor of reciprocity in early 1794.

With Hamilton's support, the Washington administration sought accommodation with Britain. The resulting Jay treaty in 1795 ruled out discriminatory trade policies for a decade. While this put an immediate end to the debate over reciprocity, supporters of manufacturing became disenchanted with the Federalists. They saw discrimination as the only way to block British access to the U.S. market. Hamilton of course supported the treaty, but Tench Coxe, a Treasury official who penned a first draft of the Report on Manufactures for Hamilton, strongly opposed it and shifted his allegiance to the Republicans.

As president, Jefferson and Madison instituted direct regulations of commerce through partial trade bans and complete embargoes. Jefferson allowed the commercial articles of the Jay treaty to expire in 1803 and rejected a proposed successor agreement. The Republicandominated Congress enacted a partial non-importation measure in 1806 , which prohibited the importation of selected British manufactured goods, although it was suspended until 1807. By that time, British and French harassment of neutral U.S. shipping forced Jefferson to propose a complete embargo on trade in December 1807.

Congress abandoned the embargo in March 1809, but replaced it with a non-intercourse law that barred all trade with Britain, France, and their colonies. ${ }^{31}$ Non-intercourse expired a year later and relatively unrestricted trade opened up again under the threat of non-importation. When this produced no relaxation in British policy, non-importation was enforced in early 1811.

31 After reaching an agreement with a British representative in Washington to lift nonintercourse in exchange for a change in British policy, President Madison opened trade in April 1809 on the assumption that the agreement would be approved by Britain. However, Britain did not approve the agreement and Madison was forced to reimposed non-intercourse in August. 
Imports of all goods made in Britain or its colonies were prohibited, although the export of American goods to those markets was allowed. The United States also maintained an embargo during the War of 1812 .

Each of these acts of commercial withdrawal were bitterly contested. A majority of the Republicans in Congress supported the trade measures, but a minority joined with Federalists in opposing them. The Federalists, drawing their support mainly from New England and New York, voted almost unanimously against every commercial restriction between 1806 and 1812 . While the promotion of domestic manufacturing was not their primary goal, the Republican trade policies had that effect and manufacturing interests swung behind them. "By the first decade of the nineteenth century, manufacturing supporters were at least as likely to be Republicans as Federalists," Peskin (2002, pp. 242-43, 235) notes, as "the parties appeared almost to switch positions on the issue of manufacturing and the role of the federal government in the economy. . .. A British traveler to Philadelphia at this time observed that the Federalist and Republican parties were respectively 'merely other terms for importers and manufacturers."' And by the time of Jefferson's embargo, Peskin (2002, p. 251) finds, “the Republican press was without a doubt far more open to a new manufacturing economy than the Federalists."

That the rhetorical gap between the Federalists and Republicans on manufacturing had narrowed considerably was evident in a report on manufactures issued by the Albert Gallatin, Treasury Secretary in the Madison administration. Issued in April 1810, Gallatin's report was much shorter than Hamilton's but reached similar conclusions. Gallatin concluded by saying that the "information which has been obtained is not sufficient to submit, in conformity with the resolution of the House, the plan best calculated to protect and promote American 
manufactures." However, he noted three ways of doing so: bounties, import duties, and government loans. Gallatin argued that bounties were most appropriate for exported goods and that high tariffs were "liable to the treble objection of destroying competition, of taxing the consumer, and of diverting capital and industry into channels generally less profitable to the nation." Therefore, since "the comparative want of capital, is the principal obstacle to the introduction and advancement of manufactures in America, it seems that the most efficient, and most obvious remedy would consisting in supplying that capital." Additional banks would help, but given their short-horizon for loans Gallatin proposed that the government create a circulating stock (of between $\$ 5$ and $\$ 20$ million) that would be lent to manufactures. ${ }^{32}$

This proposal for government loans went nowhere in Congress. But it is ironic that nearly twenty years after Madison sought to scuttle Hamilton's Report on Manufactures, his own Treasury Secretary issued a report that was strikingly similar in its pro-manufacturing stance. After the War of 1812, the Madison administration and Congress did not want to the new manufacturing industries that had arisen in the interim to disappear as a result of renewed competition from Britain. In a February 1816 report containing proposals for a new post-war tariff, Secretary of the Treasury Alexander Dallas argued that these manufacturers were "the means of future safety and independence" for the nation. Dallas stated that some "recently or partially established" manufacturers deserved government support:

"it is respectfully thought to be in the power of the Legislature, by a well-timed and welldirected patronage, to place them, within a limited period, upon the footing on which the manufacturers included in the first class have been so happily placed. . . Although some indulgence will always be required, for any attempt so to realize the national independence in the department of manufactures, the sacrifice cannot be either great or

32 American State Papers, Finance, Vol. 2, pp. 430-431. 
lasting. The inconveniences of the day will be amply compensated by future advantages." 33

Thus, the Madison administration helped give rise to the first truly protectionist tariff in U.S. history.

Jefferson fully recognized that trade sanctions against Britain would provide "indirect encouragement" to domestic manufacturing. But in contrast to his earlier views, Jefferson welcomed the growth of domestic manufacturing that occurred during the period of severe trade disruptions from 1807 to 1814 . The tumultuous experience of dealing with British trade policies after independence had transformed Jefferson from someone who had written in 1785 that farmers were "the chosen people of God" and had pleaded "let our workshops remain in Europe" to conceding in 1816 that "we must now place the manufacturer by the side of the agriculturalist." "Within the thirty years that have elapsed, how are circumstances change!" Jefferson wrote. "[E]xperience has taught me that manufactures are now as necessary to our independence as to our comfort." 34

\section{Conclusions}

Alexander Hamilton's famous Report on Manufactures has frequently been viewed as dead on arrival when presented to Congress. The report was not just a visionary document about the theoretical advantages of manufacturing, but also a policy document that made specific and concrete proposals for government action. Hamilton's report suggested only five instances in

\footnotetext{
33 American State Papers, Finance, Vol. 3, p. 90.

${ }^{34}$ Writings of Thomas Jefferson, Vol. 3, pp. 68-69, and Vol. 10, pp. 8, 10.
} 
which government bounties might prove useful. Because these bounty proposals failed in Congress, the perception has been that the report was not adopted by Congress. But most of the policy measures were changes in tariff rates - raising some tariffs on imported manufactures and lowering some tariffs on imported raw materials - and most of these policy measures were implemented by Congress within six months of the report. Furthermore, Hamilton was not as keen a supporter of manufacturing as he is sometimes made out to be. Indeed, his moderate tariff policies soon forced domestic manufacturers to embrace the much more draconian trade policies of the Republican party led by Jefferson and Madison. 
Table 1: Votes in House of Representatives

A. Vote on Bounties for Cod Fisheries, February 9, 1792

\begin{tabular}{lcc}
\hline \hline Region & Yeas & Nays \\
\hline New England & 16 & 0 \\
Mid-Atlantic & 16 & 5 \\
South & 9 & 16 \\
\hline Total & 38 & 21 \\
\hline \hline
\end{tabular}

B. Vote on Requesting Advice from Secretary of the Treasury on Financing, March 8, 1792

\begin{tabular}{lcc}
\hline \hline Region & Yeas & Nays \\
\hline New England & 14 & 2 \\
Mid-Atlantic & 12 & 11 \\
South & 5 & 14 \\
\hline Total & 31 & 27 \\
\hline \hline
\end{tabular}

C. Vote on Making Duties Temporary, April 19, 1792

\begin{tabular}{lcc}
\hline \hline Region & Yeas & Nays \\
\hline New England & 4 & 13 \\
Mid-Atlantic & 9 & 16 \\
South & 19 & 3 \\
\hline Total & 32 & 32 \\
\hline \hline
\end{tabular}

D. Vote on Final Passage of Tariff, April 21, 1792

\begin{tabular}{lcc}
\hline \hline Region & Yeas & Nays \\
\hline New England & 13 & 3 \\
Mid-Atlantic & 17 & 5 \\
South & 7 & 13 \\
\hline Total & 37 & 20 \\
\hline \hline
\end{tabular}

Source: Annals of Congress, Vol. III. 
Table 2: Actual Tariffs and Hamilton's Recommendations, Selected Commodities

\begin{tabular}{|c|c|c|c|c|}
\hline Commodity & $\begin{array}{c}\text { Tariff of July } \\
1789\end{array}$ & $\begin{array}{c}\text { Report on } \\
\text { Manufactures, } \\
\text { December } 1791\end{array}$ & $\begin{array}{c}\text { Treasury Report, } \\
\text { March } 1792\end{array}$ & $\begin{array}{c}\text { Tariff of May } \\
1792\end{array}$ \\
\hline \multicolumn{5}{|c|}{ Proposed Increases } \\
\hline Steel, raw & $75 \notin$ per cwt. & $100 \notin$ per cwt. & $100 \notin$ per cwt. & $100 \notin$ per cwt. \\
\hline $\begin{array}{l}\text { Iron, } \\
\text { manufactured }\end{array}$ & $7.5 \%$ & $10 \%$ & $10 \%$ & $10 \%$ \\
\hline Nails \& spikes & $1 \not$ per $1 b$. & $2 \not \phi$ per $1 b$. & $2 \not c$ per $1 b$. & $2 \not c$ per $1 b$. \\
\hline $\begin{array}{l}\text { Steel, } \\
\text { manufactured }\end{array}$ & $5 \%$ & $7.5 \%$ & $10 \%$ & $10 \%$ \\
\hline $\begin{array}{l}\text { Firearms \& } \\
\text { weapons }\end{array}$ & $5 \%$ & $15 \%$ & $15 \%$ & $15 \%$ \\
\hline $\begin{array}{l}\text { Carpets \& } \\
\text { carpeting }\end{array}$ & $7.5 \%$ & $10 \%$ & $10 \%$ & $10 \%$ \\
\hline Sail Cloth & $5 \%$ & $10 \%$ & $10 \%$ & $10 \%$ \\
\hline $\begin{array}{l}\text { Linens (e.g., } \\
\text { canvas, drillings, } \\
\text { baggings, etc.) }\end{array}$ & $5 \%$ & $7.5 \%$ & No mention & $5 \%$ \\
\hline Glue & $5 \%$ & $15 \%$ & $15 \%$ & $15 \%$ \\
\hline $\begin{array}{l}\text { Starch, hair } \\
\text { powder, \& } \\
\text { wafers }\end{array}$ & $5 \%$ & $15 \%$ & $15 \%$ & $15 \%$ \\
\hline Brass wares & $5 \%$ & 7.5 or $10 \%$ & $10 \%$ & $10 \%$ \\
\hline $\begin{array}{l}\text { Tin, pewter, \& } \\
\text { copper wares }\end{array}$ & $7.5 \%$ & $10 \%$ & $10 \%$ & $10 \%$ \\
\hline $\begin{array}{l}\text { Sheathing and } \\
\text { cartridge paper }\end{array}$ & $5 \%$ & make dutiable & $10 \%$ & $10 \%$ \\
\hline Printed books & $5 \%$ & $10 \%$ & $10 \%$ & $7.5 \%$ \\
\hline Cocoa & $1 \phi$ per $1 b$. & $\begin{array}{c}\text { make somewhat } \\
\text { higher }\end{array}$ & $2 \not c$ per $1 b$. & $2 \notin$ per $1 b$. \\
\hline Chocolate & $5 \%$ & $2 \not c$ per $1 b$. & No mention & $3 \not$ per $1 b$. \\
\hline
\end{tabular}


No Proposed Changes

\begin{tabular}{|c|c|c|c|c|}
\hline Skins & Free & No change & No mention & Free \\
\hline $\begin{array}{l}\text { Hemp } \\
\text { manufactures }\end{array}$ & $54 \phi$ per cwt. & No change & No mention & $100 \phi$ per cwt. \\
\hline Gunpowder & $10 \%$ & No change & No mention & $10 \%$ \\
\hline $\begin{array}{l}\text { Lead } \\
\text { manufactures }\end{array}$ & $1 \not$ per $1 b$ & No change & No mention & $1 \not$ per $l b$. \\
\hline Glass & $12.5 \%$ & No change & $15 \%$ & $15 \%$ \\
\hline \multicolumn{5}{|c|}{ Proposed Decreases } \\
\hline $\begin{array}{l}\text { Sulfur (for } \\
\text { gunpowder) }\end{array}$ & $5 \%$ & Free & No mention & Free \\
\hline Wood, raw & $5 \%$ & Free & No mention & Free \\
\hline $\begin{array}{l}\text { Copper, raw (in } \\
\text { bars or pigs) }\end{array}$ & $5 \%$ & Free & No mention & Free \\
\hline Cotton, raw & $3 \notin$ per $l b$. & Free & No mention & $10 \%$ \\
\hline Silk, raw & $5 \%$ & Free & No mention & $7.5 \%$ \\
\hline Books, academic & $5 \%$ & Free & No mention & $7.5 \%$ \\
\hline \multicolumn{5}{|c|}{ Proposed Bounties } \\
\hline Coal & $3 \notin$ per bushel & $\begin{array}{l}\text { Bounty "worthy } \\
\text { of examination" }\end{array}$ & No mention & $4.5 \varnothing$ per bushe \\
\hline Sail cloth & $5 \%$ & $2 \phi$ per yard & No mention & $5 \%$ \\
\hline Wool, raw & Free & $\begin{array}{c}\text { Amount } \\
\text { unspecified }\end{array}$ & No mention & Free \\
\hline $\begin{array}{l}\text { Cotton } \\
\text { Manufactures }\end{array}$ & $7.5 \%$ & $\begin{array}{l}\text { Bounty, } 1 \notin \text { per } \\
\text { yard \& } 1 \notin \text { per } \\
\text { lb. of domestic } \\
\text { cotton used }\end{array}$ & No mention & $7.5 \%$ \\
\hline Raw cotton & $3 \notin$ per $1 b$. & See above. & No mention & $10 \%$ \\
\hline $\begin{array}{l}\text { Window glass \& } \\
\text { black bottles }\end{array}$ & $12.5 \%$ & $\begin{array}{c}\text { Amount } \\
\text { unspecified }\end{array}$ & No mention & $15 \%$ \\
\hline
\end{tabular}

Sources: Tariff rates from Young (1873) and Hamilton's message to Congress in American State Papers, Finance, Vol. 1, pp. 158-161. 
Note: Raw cotton was duty free in the tariff act of July 1789 , but became subject to the 3 cent duty in the tariff of August 1790. The tariff on glass was $10 \%$ in the tariff act of July 1789, but became subject to the 12.5 percent duty in the tariff of August 1790 . 


\section{References}

American State Papers. Various volumes. Washington: Gales and Seaton, 1832.

Ben-Atar, Doron S. The Origins of Jeffersonian Commercial Policy and Diplomacy. New York: St. Martin's Press, 1993.

Cole, Arthur H. (Ed.). Industrial and Commercial Correspondence of Alexander Hamilton, Anticipating his Report on Manufactures. Chicago: A.W. Shaw Co., 1928.

Clarfield, Gerard. "Protecting the Frontiers: Defense Policy and the Tariff Question in the First Washington Administration.” William and Mary Quarterly 32 (July 1975): 443-464.

Cooke, Jacob E. "Tench Coxe, Alexander Hamilton, and the Encouragement of American Manufactures." William and Mary Quarterly 32 (July 1975): 369-392.

Elkins, Stanley, and Eric McKitrick. The Age of Federalism: The Early American Republic, 1788-1800. New York: Oxford University Press, 1993.

Ferling, John. A Leap in the Dark: The Struggle to Create the American Republic. New York: Oxford University Press, 2003.

Freeman, Joanne B. "“The Art and Address of Ministerial Management': Secretary of the Treasury Alexander Hamilton and Congress." In Kenneth R. Bowling and Donald R. Kennon (eds.), Neither Separate Nor Equal: Congress in the 1790s. Athens: Ohio University Press, 2000.

McCoy, Drew R. The Elusive Republic: Political Economy in Jeffersonian America. Chapel Hill: University of North Carolina Press, 1980.

Nelson, John R., Jr. "Alexander Hamilton and American Manufacturing: A Reexamination." Journal of American History 65 (March 1979): 971-995.

Nelson, John R., Jr. Liberty and Property: Political Economy and Policymaking in the New Nation, 1789-1812. Baltimore: Johns Hopkins University Press, 1987.

Peskin, Lawrence A. "How the Republicans Learned to Love Manufacturing: The First Parties and the "New Economy." Journal of the Early Republic 22 (September 2002): 235-262.

Peterson, Merrill D. “Thomas Jefferson and Commercial Policy, 1783-1793." William and Mary Quarterly, 22 (October 1965): 584-610.

Taussig, Frank W. A Tariff History of the United States. $8^{\text {th }}$ edition. New York: Putnam's, 1931.

Young, Edward. Special Report on the Customs Tariff Legislation of the United States.

Washington, D.C.: Government Printing Office, 1873. 